\title{
Sialolipoma of the sublingual salivary gland in a dog - first report
}

\section{Sialolipoma na glândula salivar sublingual em cão - primeiro relato}

\author{
Andressa Gianotti Campos ${ }^{1 *}$ (Di); Geni Patricio ${ }^{1}$; Patrícia Ferreira de Castro ${ }^{1}$ Luciane Kanayama ${ }^{1}$; \\ Alessandra Loureiro Morales dos Santos²; Bruno Cogliati²; Julia Maria Matera ${ }^{1}$
}

\begin{abstract}
${ }^{1}$ Universidade de São Paulo, Faculdade de Medicina Veterinária e Zootecnia, Departamento de Cirurgia, São Paulo - SP, Brazil
${ }^{2}$ Universidade de São Paulo, Faculdade de Medicina Veterinária e Zootecnia, Departamento de Patologia, São Paulo - SP, Brazil
\end{abstract}

\begin{abstract}
This report describes a 14-year-old Pit Bull dog presenting with a soft tissue swelling of 3-month progression in the right sublingual region. Histopathological analysis of the surgically resected specimen revealed large numbers of mature adipocytes and islets consisting of mucin-containing atrophic acini and dilated ducts surrounded by a thin fibrous capsule. Findings were consistent with sialolipoma of the sublingual salivary gland. To the authors' knowledge, this is the first case of sialolipoma affecting the sublingual salivary gland in dogs.
\end{abstract}

Keywords: Sialolipoma. Neoplasia. Sublingual salivary gland. Dog.

\section{RESUMO}

O presente relato descreve um cão Pit Bull, de 14 anos, com aumento de volume de consistência macia em região sublingual direita com evolução de 3 meses. Após excisão cirúrgica, a análise histopatológica revelou grande número de adipócitos maduros, tecido glandular composto por ductos dilatados e ácinos atróficos contendo mucina, circundados por fina cápsula fibrosa, achados compatíveis com sialolipoma da glândula salivar sublingual. Pelo conhecimento dos autores, este é o primeiro relato de sialolipoma acometendo glândula salivar sublingual em cão.

Palavra-chave: Sialolipoma. Neoplasia. Glândula salivar sublingual. Cão.

\section{Correspondence to:}

Andressa Gianotti Campos

Universidade de São Paulo, Faculdade de Medicina Veterinária

e Zootecnia, Departamento de Cirurgia

Av. Prof. Dr. Orlando Marques de Paiva, 87

CEP: 05508270, São Paulo - SP, Brazil

e-mail: gianotti@usp.br

Submited: August 16, 2018

Approved: January 16, 2019

How to cite: Campos AG, Patricio G, Castro PF, Kanayama L, Santos ALM, Cogliati B, Matera JM. Sialolipoma of the sublingual salivary gland in a dog - first report. Braz J Vet Res Anim Sci. 2019;56(1):e149060. https://doi. org/10.11606/issn.1678-4456.bjvras.2019.149060

Primary salivary gland tumors are rare and account for only $0.17 \%$ of all neoplastic conditions in dogs (Carberry et al., 1988; Hammer et al., 2001). Sialolipomas are benign adipose tissue neoplasms arising in major (parotid, submandibular, sublingual or zygomatic) and minor (salivary tissue clusters in the mouth, tongue, lips, palate, tonsils, pharynx and esophagus) salivary glands and as in humans, are uncommon in animals (Nagao et al., 2001).

A spayed Pit Bull female dog aged 14 years and weighing $28 \mathrm{~kg}$ was referred to the Small Animal Surgery Service of the Veterinary Hospital of the School of Veterinary Medicine and Animal Science of University of São Paulo with a 3-month history of swelling in the right submandibular and sublingual regions. Dyspnea and cyanosis of the tongue following exertion or exposure to stressful situations were reported. No treatment had been attempted. On physical examination, a painless soft tissue swelling could be palpated in right submandibular area, close to the ventral angle of the mandible. A second non-ulcerated, pinkish soft tissue mass arising in the right sublingual region was also noted; this mass measured approximately $10.0 \times 8.0 \times 4.0 \mathrm{~cm}$ and caused the tongue to deviate to the contralateral side. Electrocardiogram, 
complete blood count and biochemistry panel were unremarkable.

Sonographic assessment of the ventral cervical area revealed a highly hyperechoic, coarse, ill-defined area suggestive of a mass surrounded by local inflammation. Material retrieved by fine needle aspiration was not consistent with saliva; cytology was inconclusive due to blood contamination. Clinical history and physical examination suggested sublingual ranula. The dog was therefore referred for surgery. Following routine preparation of the oral cavity, submandibular and cervical areas, sialoadenectomy of the submandibular and paired sublingual glands was performed using the lateral approach. No gross changes were noted in resected glands or surrounding muscle and subcutaneous tissues. The mass located in the oral cavity was then inspected and submitted to fine needle aspiration; a fat-like material was retrieved, but no saliva. The oral mucosa was incised and the mass resected following en bloc dissection. This mass consisted of a greasy, poorly vascularized tissue encased in a thin capsule; location was consistent with the right salivary gland (Figures 1 and 2). Resected tissues (i.e., submandibular and sublingual salivary glands and the sublingual mass) were fixed in 10\% formaldehyde and submitted to histopathological analysis. Skin sutures were removed within 10 days of surgery. At that stage, the dog was in good general condition and showed no signs of mandibular or sublingual swelling. Effort-related dyspnea and cyanosis had completely resolved.

On microscopy, mature adipocytes occupied more than $90 \%$ of the mass. The adipose tissue was admixed with islands of salivary gland parenchyma surrounded by a thin fibrous (Figure 3A). Epithelial and glandular islets consisting of mucin-containing atrophic acini and dilated ducts surrounded by delicate fibrous tissue, and mild lymphoplasmacytic inflammation, were also observed (Figure 3B). Findings were consistent with sialolipoma. Submandibular glands contained multiple foci of mild lymphoplasmacytic inflammation. No evidences of neoplastic or fat cell infiltration were found. Twelve months following surgery, the dog remained in good general condition, with no evidences of recurrence.

Primary salivary gland tumors are rare in dogs and tend to be malignant and epithelial in origin (Carberry et al., 1988). Adipose tissue tumors are also uncommon, with only three cases of canine sialolipoma described to date (Clark et al., 2013; Rodiño Tilve et al., 2017). Older dogs (mean age of 10.5 years) are more commonly affected. Predilection for large to medium breeds such as Boxer, Golden Retriever, Pit Bull and Lurcher has also been described. The dog in this study was a female; likewise, female dogs were affected in two of three cases reported in literature (Clark et al., 2013; Rodiño Tilve et al., 2017).

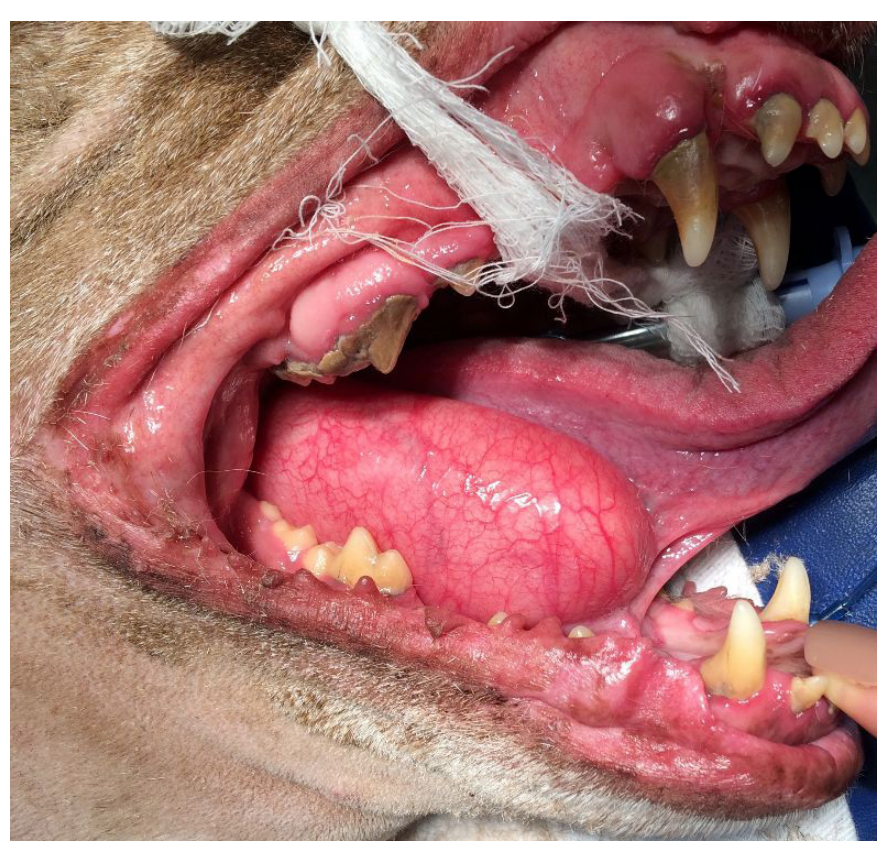

Figure 1 - Right-sided soft tissue swelling in a female Pit bull dog. Location is consistent with the sublingual salivary gland.

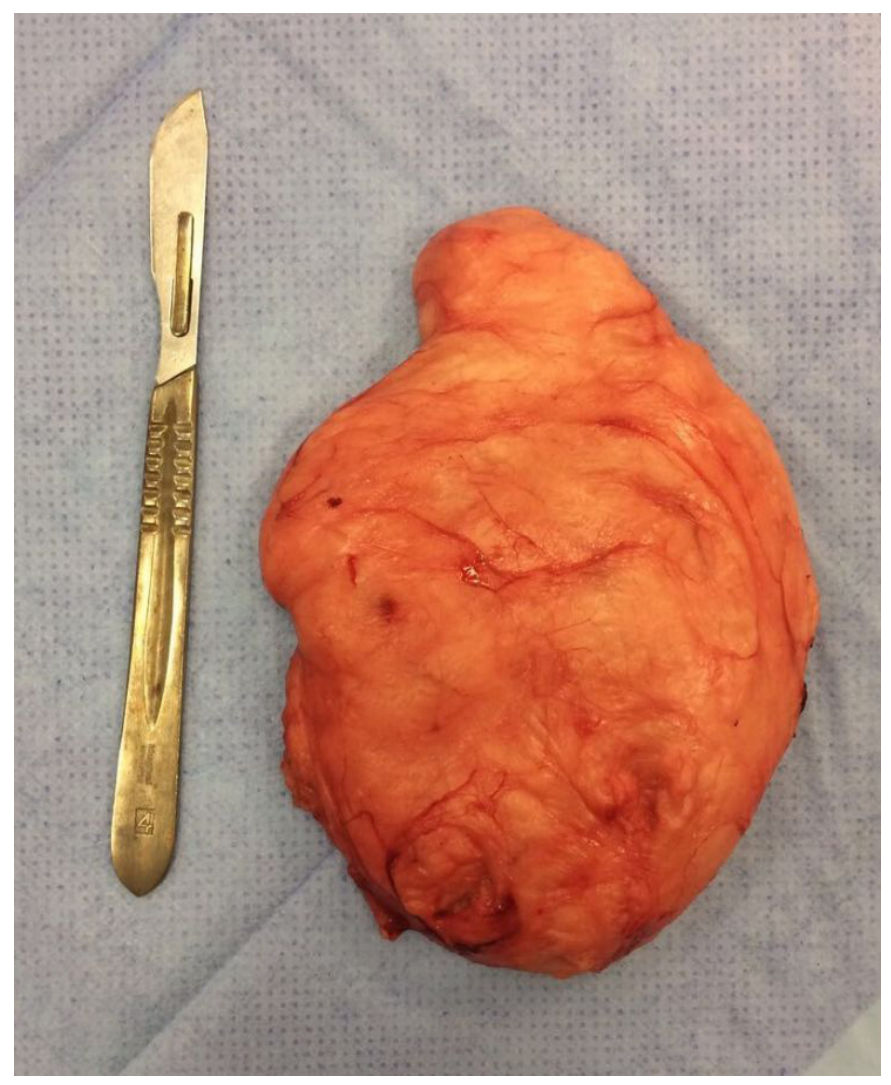

Figure 2 - Surgical specimen. Soft tissue mass measuring $10.0 \times 8.0 \times 4.0 \mathrm{~cm}$ located in the right sublingual salivary gland. Note irregular, multilobated surface, greasy appearance and whitish/brownish color. 


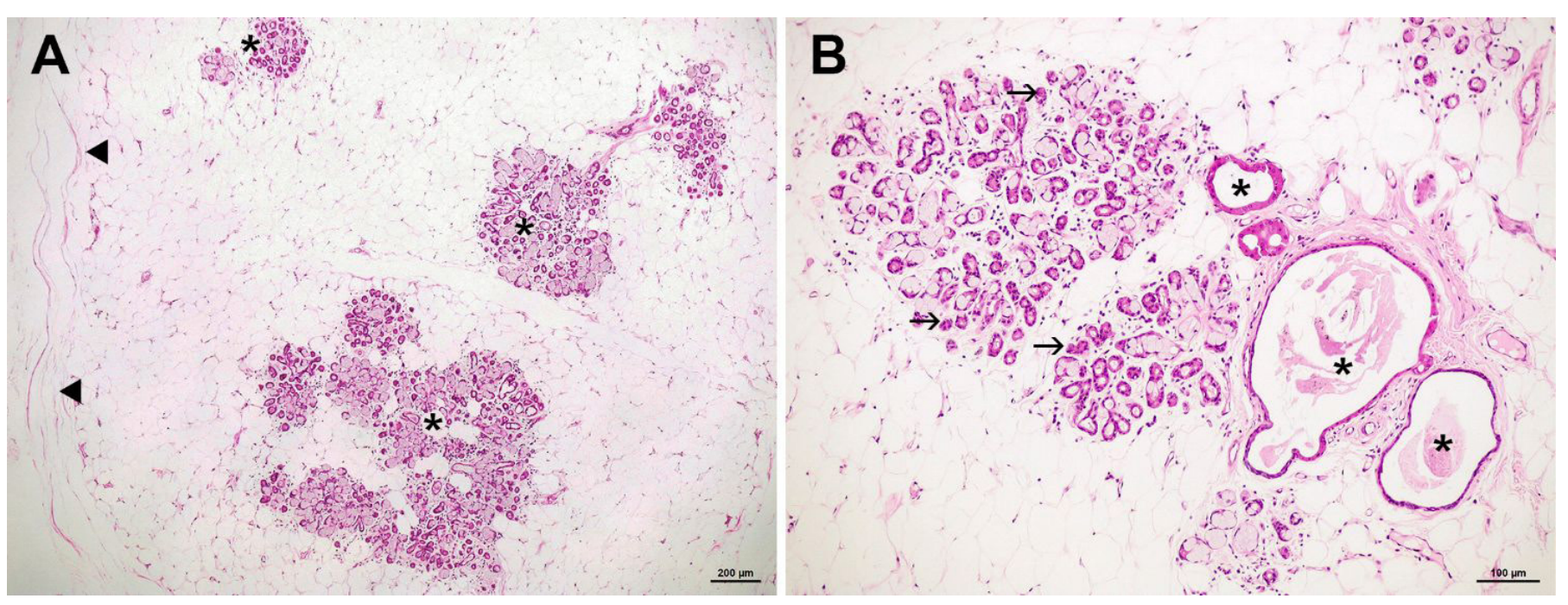

Figure 3 - Microscopic appearance of the mass arising in the sublingual salivary gland.

A) Note islands of salivary gland tissue (stars) interspersed with massive amounts of adipose tissue and surrounded by a thin fibrous capsule (arrowhead). B) Note epithelial and glandular islets consisting of mucin-containing atrophic acini (arrows) and dilated ducts (stars) surrounded by delicate fibrous tissue, and mild lymphoplasmacytic inflammation. Features are consistent with sialolipoma.

The etiology of sialolipomas remains to be determined. Glandular dysfunction leading to structural changes in acini and ducts, and ultimately to replacement of glandular parenchyma with mature adipose tissue, has been suggested (Akrish et al., 2011). Histologically, sialolipomas consist of large amounts of encapsulated mature fat tissue interspersed with normal salivary parenchyma, with no atypical features. Acini and glandular ducts may be normal, atrophic or dilated, and may be found at the periphery or central portion of the lesion (Nagao et al., 2001). As in previous reports, fat tissue accounted for $90 \%$ of the mass volume in this study, the remaining $10 \%$ consisting of glandular tissue.

In humans and animals, fat-containing salivary gland tumors are uncommon and difficult to designate and classify given their wide histomorphological spectrum. These tumors may be broadly categorized into typically adipocytic neoplasms (lipomas, fibrolipomas, angiolipomas, and liposarcomas and others) or lipoepithelial neoplasms containing different proportions of epithelial cell and fat components, such as pleomorphic adenomas and sialolipomas (Agaimy, 2013). Lipomatosis (i.e., lipomatous infiltration characterized by diffuse adipose infiltration leading to generalized salivary gland swelling) has also been described (Agaimy, 2013; Madarame et al., 2015). Lipomas, angiolipomas, lipomatosis and lipoadenomas are the major differential diagnoses in dogs, and are histologically distinguished by lack of a distinct fibrous capsule (Nagao et al., 2001). Non-neoplastic differentials include sublingual ranula, salivary cyst, sialocele, abscess and foreign bodies (Spangler \& Culbertson, 1991).
Clinically, sialolipomas present as soft, whitish, non-ulcerated soft tissue masses within the salivary glands. These masses may mobile or sessile and are often painless and slow-growing. Depending on their location and size, digestive tract or airway obstruction, dyspnea and/or dysphagia may result (Akrish et al., 2011).

In humans, sialolipomas arise primarily in the parotid (51.4\% of cases), followed by the mandibular gland (Pandey et al., 2015). Tumors arising in the parotid gland or tonsillar fossa (two and one case, respectively) have been reported in dogs (Clark et al., 2013; Rodiño Tilve et al., 2017). In this study, the tumor affected the monostomatic portion of the sublingual salivary gland and extended up to the junction with the submandibular gland, which explains the soft tissue swelling palpated on the caudal aspect of the mandible.

Ultrasonography combined with computed tomography and/or magnetic resonance imaging allows visualization of homogeneous, partially septated masses without contrast enhancement, and is the method of choice for diagnostic assessment of the salivary glands (Gritzmann et al., 1988). In the case described, sonographic changes in the cervical and submandibular regions were limited to increased tissue echogenicity (likely reflecting displacement of submandibular tissues by the sublingual mass), as delineation of the neoplastic mass was not possible. The owner refused to proceed with computed tomography and opted for surgical treatment, in spite of the lack of a definitive diagnosis.

Surgical resection of the affected gland is the treatment of choice for sialolipoma and the prognosis is good, with no metastases or recurrence reported in affected patients 
(Nagao et al., 2001). The dog in this study had no signs of recurrence within 12 months of surgery. Still, a longer follow-up period is recommended. To the best of our knowledge, this is the first case of canine sublingual sialolipoma to be reported. Ranula is the most common pathological condition affecting this gland in dogs. However, sialolipoma should be considered in the differential diagnosis of intraoral masses in this species.

\section{References}

Agaimy A. Fat-containing salivary gland tumors: a review. Head Neck Pathol. 2013;7(Suppl 1):S90-6. http://dx.doi. org/10.1007/s12105-013-0459-7. PMid:23821211.

Akrish S, Leiser Y, Shamira D, Peled M. Sialolipoma of the salivary gland: two new cases, literature review, and histogenetic hypothesis. J Oral Maxillofac Surg. 2011;69(5):1380-4. http:// dx.doi.org/10.1016/j.joms.2010.05.010. PMid:21256655.

Carberry CA, Flanders JA, Harvey HJ, Ryan AM. Salivary gland tumors in dogs and cats: a literature and case review. J Am Anim Hosp Assoc. 1988;24:561-7.

Clark K, Hanna P, Béraud R. Sialolipoma of a minor salivary gland in a dog. Can Vet J. 2013;54(5):467-70. PMid:24155429.

Gritzmann N, Schratter M, Traxler M, Helmer M. Sonography and computed tomography in deep cervical lipomas and lipomatosis of the neck. J Ultrasound Med. 1988;7(8):451-6. http://dx.doi.org/10.7863/jum.1988.7.8.451. PMid:3047424.

Hammer A, Getzy D, Ogilvie G, Upton M, Klausner J, Kisseberth WC. Salivary gland neoplasia in the dog and cat: survival times and prognostic factors. J Am Anim Hosp Assoc. 2001;37(5):478-82. http://dx.doi.org/10.5326/1547331737-5-478. PMid:11563448.

Madarame H, Harada R, Kawarai S, Takeda H, Shida T. Lipomatosis of the canine parotid gland: case report with a literature review. J Toxicol Pathol. 2015;28(4):229-32. http://dx.doi.org/10.1293/tox.2015-0027. PMid:26538813.

Nagao T, Sugano I, Ishida Y, Asoh A, Munakata S, Yamazaki K, Konno A, Kondo Y, Nagao K. Sialolipoma: a report of seven cases of a new variant of salivary gland

\section{Conflict of interest}

The authors declare no conflict of interest.

\section{Ethics Statement}

The manuscript is a clinical case report, whose diagnostic and therapeutic conduct adopted in the patient in question followed the precepts established in literature, and therefore the approval of the ethics committee of the institution was not required.

lipoma. Histopathology. 2001;38(1):30-6. http://dx.doi. org/10.1046/j.1365-2559.2001.01054.x. PMid:11135044.

Pandey D, Vats M, Akhtar A, Pathania OP. Sialolipoma of the parotid gland: a rare entity. BMJ Case Rep. 2015;2015:1-4. PMid:26082099. http://dx.doi.org/10.1136/ bcr-2014-209264

Rodiño Tilve V, Finck M, Leach JDG, Macfarlane MJ. Sialolipoma of the parotid salivary gland in two dogs. Vet Rec Case Rep. 2017;5(2):e000376. http://dx.doi.org/10.1136/ vetreccr-2016-000376.

Spangler WL, Culbertson MR. Salivary gland disease in dogs and cats: 245 cases (1985-1988). J Am Vet Med Assoc. 1991;198(3):465-9. PMid:2010345.

Financial support: The manuscript titled did not receive financial support from any funding institution.

Authors Contributions: Andressa Gianotti Campos was responsible for patient's surgical procedure and follow up; bibliographical and written survey of the manuscript; Geni Patricio was responsible for anesthesia and post-operative care of the patient; Patrícia Ferreira de Castro contributed to collection of medical data and helped writing the manuscript; Luciane Kanayama performed diagnostic images and helped writing the manuscript; Bruno Cogliati and Alessandra Loureiro Morales dos Santos contributed to the histological/immunohistochemical evaluations; Julia Maria Matera was responsible for patient's surgical procedure and revision of manuscript providing critical feedback. 